\title{
Research on Wildlife Protection Strategies Based on the Idea of Ecological Civilization
}

\author{
Chengduan Wang1', Zibiao Cheng'2, Biying Cheng ${ }^{3}$ \\ ${ }^{1}$ Party Committee Office, Sichuan University of Arts and Science, Dazhou, China \\ ${ }^{2}$ School of Finance and Economics Management, Sichuan University of Arts and Science, Dazhou, China \\ ${ }^{3}$ Academic Affairs Office, Sichuan University of Arts and Science, Dazhou, China \\ Email: 47872614@qq.com
}

How to cite this paper: Wang, C. D., Cheng, Z. B., \& Cheng, B. Y. (2020). Research on Wildlife Protection Strategies Based on the Idea of Ecological Civilization. Voice of the Publisher, 6, 131-139. https://doi.org/10.4236/vp.2020.63015

Received: September 2, 2020

Accepted: September 20, 2020

Published: September 23, 2020

Copyright $\odot 2020$ by author(s) and Scientific Research Publishing Inc. This work is licensed under the Creative Commons Attribution International License (CC BY 4.0).

http://creativecommons.org/licenses/by/4.0/

\begin{abstract}
This paper discusses the relationship between wildlife protection and ecological civilization construction. It also puts forward some wildlife protection strategies based on the idea of ecological civilization, such as improving the national provincial and municipal nature reserves, and further improving laws and regulations related to the wild animals conservation law. The competent departments of animal administrative law enforcement and all units should strictly enforce the law. The domestication, reproduction. Development and utilization of wild animals should be carried out in accordance with the law. Publicity and education on ecological civilization should be further strengthened.
\end{abstract}

\section{Keywords}

Wildlife Protection, Ecological Civilization, Strategies

\section{Introduction}

Since December 2019, the COVID-19 epidemic in Wuhan has aroused the concern of the Party and people of all ethnic groups in China. The CPC Central Committee and the State Council have attached great importance to it. General Secretary Jinping $\mathrm{Xi}$ has personally made arrangements and directed several meetings on epidemic prevention and control, leading the people of all ethnic groups in China to fight the overall and blocking battle against the epidemic. The research results published by various research teams all showed that wild animals were the host of this novel coronavirus, which caused the epidemic outbreak due to the illegal consumption of wild animals and other reasons. The bio- 
tic and abiotic components of an ecosystem maintain a close relationship between interaction and interdependence through the flow of matter and energy. Man and nature belong to the same ecosystem and life community, wild animals are the core subsystem of the natural ecosystem, and the protection of wild animals is the core to realize the harmonious coexistence and coordinated and comprehensive development between man and nature (Hong, Zhang, Zhang, Kang, Cheng, Gu, Li, Shen, Wang, Huang, \& Yang, 2020). The protection of wild animals is not only the protection of human beings, but also an important measure to maintain the ecological balance of the earth, which is of great significance to the construction of ecological civilization.

\section{The Relationship between Wildlife Protection and Ecological Civilization Construction}

\subsection{Protecting Wild Animals Is the Inherent Requirement of Ecological Civilization Construction}

\subsubsection{Protecting Wild Animals Is the People's Thirst for a Better Life}

In his work report to the $19^{\text {th }}$ National Congress of the Communist Party of China (CPC), General Secretary Jinping Xi clearly pointed out that "after long-term efforts, socialism with Chinese characteristics has entered a new era, which is a new historical juncture in China's development." and stressed that "The principal contradiction in our society has been transformed into one between unbalanced and inadequate development and the people's ever-growing needs for a better life." It can be seen that the development of society has accelerated people's perception and judgment of life. People are no longer satisfied with the material life, but have increasingly higher requirements on the natural environment such as air, water, plants and animals, as well as the spiritual and cultural environment such as entertainment.

The construction of ecological civilization is a historical event that concerns the happiness of the Chinese people and the prosperity of the nation, as well as an important strategic historical task of the whole Party and the whole country. At present, we are still in the primary stage of socialism. Market mechanisms need to be improved, policies and regulations are not systematic enough, and management methods and technologies need to be strengthened. In some places, environmental pollution is serious, ecosystem functions are degrading and public awareness of environmental protection is not high enough. Since the $18^{\text {th }} \mathrm{Na}-$ tional Congress of the Communist Party of China (CPC), the state attaches great importance to the ecological civilization of modern construction and takes it as an important measure and content to promote "five-sphere integrated plan" and "the four-pronged comprehensive strategy" in a coordinated way and has given high priority to promoting ecological modernization and sound development, and carried out a series of fundamental, ground-breaking and long-term projects. The report to the $19^{\text {th }}$ National Congress of the Communist Party of China pointed out that "the modernization we want to build is one in which 
man and nature coexist in harmony". An important essence of China's ecological modernization is to enrich and improve people's material, spiritual and cultural lives. One of the people's aspirations and growing demands for a better life is to build a beautiful and harmonious China.

\subsubsection{Protecting Wild Animals Is an Inevitable Choice in the New Era}

Engels pointed out, "Let us not revel too much in our human triumph over nature. For every such victory, nature takes revenge on us." The first cases of asthma or chronic pneumonia were all linked to the Huanan seafood wholesale Market in Wuhan, Hubei province, according to the Wuhan Health Commission. According to the investigation, there were illegal wild animals sales in the South China seafood wholesale market in Wuhan, and several seafood stores illegally sold bamboo rats, Paguma larvata, bats and other wild animals. In addition to Wuhan in Hubei province, wild animals such as Paguma larvata are illegally sold and sold in various parts of the country. However, the illegal sale of wild animals such as Paguma larvata and bats runs counter to the national ecological civilization construction, seriously damaging the ecosystem and causing extremely serious adverse effects on public health and life, economic and social stability and development. One of the biggest characteristics of the new era is to keep the balance and beauty of the ecological environment, protecting wild animals according to law is an inevitable choice for China to enter the new era of socialism with Chinese characteristics, and the construction of ecological civilization is an indispensable connotation of socialism (Chen, 2008).

General Secretary Jinping Xi has mentioned on many important occasions the basic principle of "harmonious coexistence between man and nature" in ecological civilization construction. In the human ecosystem, biological protection plays a unique and important role, and wild animals protection is an important part of human ecosystem construction. The natural value of wild animals in biological medicine, scientific research, ecological maintenance and other aspects has been fully highlighted, and also created abundant available resources for the social and economic development of human beings. Therefore, wild animals are closely related to our life. Strengthening protection is not only an obligation, but also the responsibility of every one of us.

Agricultural civilization provides food for mankind, industrial civilization provides wealth for mankind, and ecological civilization provides a beautiful environment for mankind. Ecological civilization is the reflection and summary of human beings on the traditional form of civilization, especially on the antagonistic relationship between human and nature in the era of industrial civilization. It is a major progress in the form of human civilization and the concept, path and mode of civilization development (Liu, 2011). Ecological civilization is the advanced form of human civilization ( $\mathrm{Yu}, 2005)$. China is one of the countries with the most abundant biological quantity and species. To protect the natural biodiversity, maintain the balance between man and nature, and promote the harmonious coexistence and healthy development of man and nature are the 
inevitable internal requirements of the national ecological civilization construction.

\subsection{Protecting Wild Animals Is the Core Content of Ecological Civilization Construction}

\subsubsection{The Protection of Wild Animals Is an Important Factor in Natural Ecosystems}

Since ancient times, China has a vast territory, varied terrain and climate, and the diversity of species has made us one of the countries with the most abundant biodiversity in the world. According to statistics, there are more than 6000 vertebrates in China, among which there are more than 500 kinds of animals, 1258 kinds of birds and 295 kinds of amphibians. In addition to the number and ecological diversity of wild animals in China, there are also hundreds of unique rare wild animals such as giant panda, crested ibis, golden monkey, South China tiger, Chinese alligator and so on. Some of these rare wild animals are rare in the world and some are unique to China. They have important scientific research and great social, economic and cultural value (Wang, 2014; Guo, 1995). In recent years, China has been increasing the protection of wild animals, but with the development of human civilization, it has posed a great threat to the natural survival and reproduction of wild animals. Wild animals such as wild horses, Saiga antelope and elk, which originated in China, have been extinct in the wild, and dozens of wild animals such as gibbons and Siberian Tigers, whose distribution range is shrinking day by day, are facing extinction. The reasons include global climate change or natural disasters, which directly cause animals' discomfort in life. However, the most important reason is that human beings cut down trees and destroy the living environment of animals. In addition, they recklessly catch and eat wild animals, which breaks the balance of ecological system.

\subsubsection{The Protection of Wild Animals Is the Premise of Harmonious Coexistence between Man and Nature}

With the rapid development of science and technology, the utilization of natural resources is increasing day by day, which has greatly broken the natural ecological environment system. However, the relationship between human beings and wild animals is a symbiotic relationship. They live in the whole nature together with human beings. Many wild animals are born earlier than human beings and have made great contributions to the evolution of life on earth. Man should not and cannot destroy the symbiotic relationship between man and wild animals. Thousands of years of history tell us that in order for human society to achieve benign survival and development, we must protect and respect nature, comply with nature, protect nature, and live in harmony with other wild animals. Otherwise, nature will return human beings' abuse to nature equally or even more. In history, a series of new human infectious diseases have appeared in the world, such as Hendra, H7N9 avian influenza, Ebola virus, Novel Coronavirus and so on, whose outbreaks occur at different times and places, but all are associated 
with wild animals. Human beings are the products of nature, and nature is the common mother that breeds human beings and other creatures. The outbreak of virus is mother Nature's "illness", and it is also nature's wake-up call to human beings to protect wild animals. If such lessons are not learned, mother Nature will become more and more ill.

Marxist ecological philosophy emphasizes the interdependence of man and nature. China is a large country rich in natural resources, especially the wild animals resources. It is a matter of pride to have such a rich variety of rare wild animals, as well as some unique wild species. However, it should also be treated with caution that every wild animal plays a vital role in the ecosystem. If we do not strengthen the core measure of wild animals protection, mother Nature will sometimes become ill. The Party Central Committee has fully recognized this problem and is actively promoting the construction of ecological civilization in China.

\subsection{Protecting Wild Animals Is the Key to the Construction of Ecological Civilization}

\subsubsection{Protecting Wild Animals Is the Key to the Healthy Survival and Development of Human Beings}

From the perspective of human sociology, whether or not to effectively protect the good ecological environment is an important symbol of a country and a nation's development and progress, and is also the cause and key to the rise and fall of civilization. From the point of view of natural ecology, the protection of a natural biological species may mean the protection of a biological community, a natural ecosystem, and conversely, it means the destruction of a natural ecosystem. Any biological system and species on the earth are necessarily interrelated. The mutual destruction of any biological system and species will directly affect and even affect the ecological balance of the entire human race and the earth, and directly affect the healthy survival and development of the entire human race. Wild animals are an important factor to maintain the ecological balance of the whole earth, and the protection of wild animals is the key to maintain the ecological balance and protect the ecological home.

\subsubsection{Protecting Wild Animals Is Key to Maintaining the Balance of Ecosystems}

Since the birth of man, the interaction between man and nature has been going on all the time. All kinds of creatures can be connected with nature through the biological chain, and live and die together with each other. Mountains, rivers, forests, fields, lakes and grasses, are indispensable to the existence of wild animals, without the existence of which, the biological chain is broken, the ecological environment will gradually degenerate. The food chain maintains a natural balance of numbers between humans and species. For example, the extinction of the owl cannot completely control the number of voles so voles will have unlimited reproduction and the proliferation of voles will cause crop decline, leading to human famine and other problems, causing a series of social problems. 
Therefore, the destruction of wild animals on a large scale will often cause a series of chain reactions on human beings. Once the biological chain is out of balance, human beings will also be affected and even have serious consequences. The protection of wild animals is the key to maintain the ecological balance.

Nowadays, human economy and society are gradually forming such a consensus that the relationship between human and nature is a harmonious coexistence of nature, and the final result of harming nature will directly harm human beings themselves. Promoting ecological progress is an inherent basic requirement for us to build a community of relationships between human and nature. How to be kind to wild animals and live in peace with them is a key component and an important link in the process of building an ecological civilization system. The SARS outbreak in 2003 and the current COVID-19 outbreak may be caused by humans' failure to live in harmony with wild animals. The occurrence and harm of the two major disease epidemics have sounded a deadly alarm bell for the excessive hunting and killing of wild animals. In accordance with the basic requirements of building a beautiful ecological civilization, we should make greater efforts to address the root causes of the problem, step up efforts to protect wild animals, and actively create an environment and good atmosphere for people to live in harmony with nature, especially with wild animals.

\section{Measures to Protect Wild Animals and Promote Ecological Civilization Construction}

Affected by the novel coronavirus outbreak, the whole country will have a deeper understanding and reflection on the significance and importance of wild animals protection. In order to accelerate the construction of ecological civilization and carry out the protection of wild animals, the following countermeasures are proposed.

\subsection{Improve the National Provincial and Municipal Nature Reserves}

According to the standard of construction standards of nature reserves strictly, we should constantly enrich the types and quantity of nature reserves, to ensure the reasonable regional distribution, strengthen management of the existing nature reserves to ensure that the nature reserves play the most effective role in ecological construction, in combination with the construction and protection of ecological environment, we should make great efforts to study how to protect and cherish endangered wild animals. Through the construction of nature reserves, the implementation of ecological industry and the protection of wild animals and plants on the spot to construct a better living environment for wild animals and plants.

\subsection{Further Improve Laws and Regulations Related to the Wild Animals Conservation Law}

After being approved by Standing Committee of the National People's Congress 
on November 8, 1998, the National Wildlife Protection Law has been amended four times, namely on August 28, 2004, August 27, 2009, July 2, 2016 and October 26, 2018. However, the newly amended wild animals conservation law focuses on management and protection requirements on the whole, while it is relatively light in terms of punishment, vague in terms of criminal punishment, and does not have clear provisions on sentencing. The statement is "if a crime is constituted, criminal responsibility shall be investigated according to law", so it is not practicable in implementation and has little deterrent effect. It is suggested to further improve the most powerful criminal legal means (Jiang, 2019), clarify the elements of a crime and the corresponding sentencing period, and make the current legal provisions conform to the actual needs of the society. For example, bats are harmful to human health and safety and easy to transmit viruses, but they do not belong to the wild animals under special protection. Therefore, the existence of similar situations should be considered in the legislative process.

\subsection{The Competent Departments of Animal Administrative Law Enforcement and All Units Strictly Enforce the Law}

Supervision and law enforcement should be further strengthened to crack down on illegal wild animals hunting, trafficking, trading, buying or eating behaviors that endanger wild animals. We should further strengthen the supervision and accountability mechanism, implement a management mechanism with clear rewards and punishments, and bring perpetrators to justice through various means, such as rewarding reports, surprise inspections and routine inspections, so as to curb the hunting and selling of wild animals for food. Technical departments should increase input in the monitoring and prevention of wild animal epidemic diseases, keep abreast of the latest developments of the epidemic virus and do a good job in prevention.

\subsection{The Domestication, Reproduction, Development and Utilization of Wild Animals Should Be Carried Out in Accordance with the Law (Chen, 2003)}

Under the socialist market economy system, wild animal resources have important social, economic and cultural value. It will be a new social and economic growth point to develop and utilize wild animals rationally and realize the industrialization of wild animals domestication and protection.

\subsection{Publicity and Education on Ecological Civilization Should Be Further Strengthened}

The protection of biodiversity and publicity and education on ecological environment should be strengthened according to different levels. In accordance with the principles of integrating ecological and environmental protection with sustainable development and combining theory with practice, national education, social education and community education will be put on the agenda of government institutions. If we take the COVID-19 outbreak as an opportunity 
for publicity, we can organize targeted subjective publicity and education on the construction of economic, social and ecological civilization through various media such as online videos, TV broadcasts, newspapers and magazines, mobile phone text messages and public accounts tweets, to raise the public's awareness of participating in the construction of ecological civilization, so that the public can fully understand and correctly understand the importance of protecting wild animals and the dangers of eating wild animals as well as raise the people's level of ecological progress, encourage them to participate in wild animals protection, and give full play to their dominant position. The majority of citizens should consciously establish the ownership consciousness of participating in the protection of wild animals, and consciously resist the "money temptation", resist the trade in and illegal trade in wild animals and their meat and fur, abandon the wrong idea of "game tonic" diet, set up the new fashion of civilized life and healthy diet, consciously abide by the state's policies and laws and regulations on wild animals protection, boldly report and expose illegal activities, actively cooperate with relevant law enforcement departments and consciously become a member of wild animals protection.

\section{Conclusion}

Ecological progress is a major task in China's economic and social development, and a thousand-year plan for sustainable and prosperous development of the country and the Chinese nation. Wild animals are important protector and component of the natural ecosystem. The protection of wild animals is the inherent requirement, core content and key action of ecological civilization construction. We should fully absorb the experience of the COVID-19 epidemic and earnestly implement the important spirit of the $18^{\text {th }}$ and $19^{\text {th }}$ National Congresses of the CPC for accelerating ecological progress. We should use and protect wild animals resources, maintain the ecological balance of nature to promote the harmonious development of man and nature and promote the sustainable development of human society and the natural world.

\section{Fund Project}

Sichuan Provincial Social Sciences Research High-level Research Team: Sichuan Old Revolutionary Base Areas' Ecological Civilization Construction Research Team (Project No.: 18SCTD01), Sichuan Old Revolutionary Base Development Research Center (Project No: SLQ2020SB-02), Sichuan Center For Rural Development Research (Project No: CR2003).

\section{Conflicts of Interest}

The authors declare no conflicts of interest regarding the publication of this paper.

\section{References}

Chen, T. X. (2003). The Protection of Wild Animals is the Key to the Construction of 
Ecological Province. Zhejiang Today, 16, 37.

Chen, X. M. (2008). The Enlightenment of "Ecological Marxism" to Our Construction of Ecological Civilization. Fudan University Journal, No. 4, 10.

Guo, M. Z. (1995). Current Situation and Protection Measures of Wild Animals Resources in China. Biology Teaching, 8, 45.

Hong, Z. L., Zhang, H. T., Zhang, G. W., Kang, S. Z., Cheng, S. K., Gu, S. Z., Li, J. Y., Shen, L., Wang, Y. F., Huang X. S., \& Yang, S. L. (2020). Uphold Harmony between Man and Nature and Promote Ecological Progress-Expert Pen on 'Beautiful Qinling and Bashan. Journal of Natural Resources, No. 2, 493.

Jiang, L. X. (2019). The Criminal Law Orientation of Wild Animals Resource Protection in China. Journal of Foshan University of Science and Technology, 37, 33.

Liu, J. (2011). A Study on Building a Socialist Ecological Civilization with Chinese Characteristics. Party School of the Central Committee of CPC.

Wang, C. L. (2014). A Beautiful China Cannot Be Built without Wild Animals Protection. China Population, Resources and Environment, 24, 393.

Yu, K. P. (2005). Scientific Development Concept and Ecological Civilization. Marxism and Reality, No. 4, 4 . 